\title{
Sustaining Student Enrolment: Impact of Demand Trends for Higher Education in Russia*
}

\author{
Irina Abankina, Liudmila Filatova \\ National Research University Higher School of Economics, Moscow, Russia
}

\begin{abstract}
The higher education system, a field of activity that defines the requirements for professional qualifications, that can impact structural changes in employment and foster dynamic economic development and increased competition, was one of the first sectors to be exposed to market failure. Issues of better access to higher education in various countries increasingly fit specific consistent patterns as desired results are achieved: from positive effects in the initial stages to problems that prevent growth in the number of students in the state-subsidized segment at subsequent stages, including the rigid regulation by the state. To confirm similar processes against the background of the demographic problems in Russia affecting the number of students, an empirical analysis was performed to reveal the factors influencing a surge in demand on the basis of an assessment of the correlation of a higher education resource base, production, and the industrial capacity of a region's development. This study shows successive stages of change in the public demand for higher education and confirms the justified consequences of the transition to decisive actions pertaining to the optimization of educational, material, technical, financial, and intellectual resources.
\end{abstract}

Keywords: Russia, demand for higher education, student enrolment, industrial capacity of regions, financial solvency of a population

Over time, the demand for higher education in Russia has fundamentally changed under the influence of external and internal factors. However, despite adverse circumstances, the Russian system of higher education succeeds in matching the level of many other countries that maintains a number of students pursuing advanced degrees.

The globalization of economic knowledge and demographic changes in many countries has resulted in a growing demand for higher education alongside simultaneous cuts in state financing, forcing universities to increasingly rely on tuition fees and seek out alternative income sources to ensure economic sustainability (Araya \& Peters, 2010; Sheng-jun, 2011).

However, American scholars (using a two-stage least squares model to study the supply and demand in enrolment to state-funded higher education institutions) have demonstrated certain difficulties in keeping a

\footnotetext{
* This study was implemented in the framework of the Programme of Fundamental Studies 2014 (Identifier No. 31), Higher School of Economics, Moscow.

Irina Abankina, Ph.D. in economics, professor, director, Institute for Education Studies, National Research University Higher School of Economics; research fields: economics of education, education funding, education policy, organizational and economic mechanisms, and legal issues of education development. E-mail: abankinai@hse.ru.

Corresponding author: Liudmila Filatova, Ph.D. in economics, senior researcher, Center for Applied Economic Research, Institute for Education Studies, National Research University Higher School of Economics; research fields: economics of education, higher education funding, and education policy. E-mail: lmfilatova@hse.ru.
} 
stable acceptance level while tuition fees increase (Berger \& Kostal, 2002). To confirm this finding, Berger and Kostal note that to maintain an existing offer level on the higher education market, states are obliged to increase the number of legislative regulations, otherwise, it would be necessary to decrease the offer on the education market by cutting the finances allocated for higher education by the states' authorities. The processes similar to those described by Berger and Kostal (2002) define the higher education system in Russia during the period 2006-2010.

However, to maintain high education quality, some countries introduce restrictions on the number of state-subsidized student slots in the universities (Impact of the Economic Crisis on European Universities, 2011). In some universities, budget constraints cause the closure of certain educational programmes. Many universities across Europe are changing as a result of the mergers of institutions or departments and chairs inside institutions.

These studies show trends of the changes in public demand for higher education that at the initial stages are accompanied by an increase in student enrolment. However, the imminent increase of tuition fees then results in a decrease of financial solvency of a population and, subsequently, a decreased influx of students and finances. These changes conflict with the interests of educational institutions. As early as the initial stage, state authority intervention is aimed either at adjusting the legislative base to maintain a sensible balance of education levels or at taking measures to cut expenses.

The detected trends in demand for higher education in the Russian higher education system are determined by developing three stages that have been confirmed through the course of empirical studies.

The remainder of this paper is organized as follows. In the next section, the authors briefly discuss the existing empirical evidence on the effect of increasing public demand for higher education in different countries. In the third section, they present the main characteristics of the Russian higher education system, putting the analysis into context. Then, in the fourth section, they present the data, variables, and methods. In the fifth section, they present the empirical results. The last section discusses the primary findings and conclusions.

\section{Existing Empirical Evidence}

To promote public demand for higher education, different countries have developed similar strategies that use financial leverage aimed at raising tuition fees and simultaneously implementing imperative social stimulation policy for students from low-income households.

For example, in Argentina, family income is one of the key factors (after considering other social and demographic characteristics) influencing enrolment at state and private universities. Empirical studies show that young people from families with higher incomes are more likely to have a university education and this is confirmed by the positive values of factors on household income per capita. However, the major problem preventing an increase in the number of students in the state segment is strict constraints on higher education financing in the country. To enhance the efficiency of higher education, it has been suggested that a tuition-paying system be introduced to stimulate scholarships and student loans that will attract the most talented students from low-income families. The authors believe that this would have a positive impact on higher education and increase the number of university graduates in Argentina (Rozada \& Menendez, 2002).

Turkish scholars arrived at very similar conclusions in the course of their research in Turkey. Econometrical analysis (based on Heckman's three-stage selection model) suggests that students from 
high-income households perform better on entrance exams and are more likely to attend universities that receive larger subsidies from the government (Caner \& Okten, 2013). To promote greater public demand for higher education, it has been suggested that tuition fees for education at state universities be raised along with compulsory financial assistance for students from low-income families.

A study of the results from a natural experiment in Germany (upon introduction of tuition fees in seven out of 16 federal states in 2007) confirms there is considerable influence on changes in the number of students (Bruckmeier \& Wigger, 2014; Huebner, 2012). An empirical approach to justify a hypothetical situation of the influence of countrywide tuition fees in German states shows an increase in the number of students of up to 6.85 percentage points.

A significant contribution in the successful enrolment of students in universities is noted for Finland, where an efficient policy of educational financing as an instrument for overcoming social inequality is used (Partanen, 2011). This allowed students from various social and economic strata to increase their enrolment results (Sahlberg, 2011).

The education system in Finland succeeded in guaranteeing primary and secondary levels of education. However, for the university education system, it is necessary to enhance research programmes and generate creative ideas as a foundation for innovative development and economic progress. These conclusions can be directly linked to the assertion of the authors that effective education contributes to an improvement in the economic performance of each country and can mitigate resulting financial pressures by spurring growth in overall purchasing power (Sheng-jun, 2011; Wolff, Baumol, \& Saini, 2014).

\section{Russian Higher Education System}

The education services market in Russia undergoes dramatic changes under the influence of demographic decline, financial crises, and the shrinking of effective household demand for higher education. In 1995-2005, rapid development, the expansion of state universities, and the growth of new types of higher educational institutions contributed to the extensive growth of the higher education market. That period is characterized by the highest rates of consumer demand and a wide range of educational offerings from both state and private higher education institutions. The period's distinguishing feature was the prevalence of tuition-paying students; since 2002, their number grew faster (117\%) than that of the state-subsidized students (103\%).

The period, on the back of declining demand, was marked by the large-scale training of specialists within popular specializations. In other words, consumer demand reacted primarily to the offerings of the higher education market in the most popular areas of training such as economics, management, liberal arts, education, and pedagogy (see Figure 1). At the time, the market was flooded by specialists in areas that were especially attractive to the general population, and the tuition-paying study modes (mostly part-time education and education by correspondence) in the state and private segments of higher education encouraged that trend. Therefore, engineering and the technical educational segment was sidelined and this caused pronounced differentiation in the study areas (I. Abankina, T. Abankina, Filatova, Nikolayenko, \& Seroshtan, 2012).

The demographic decline led to a reduction in the number of secondary school graduates, which since 2006, has had a direct influence on the enrolment rates of higher education institutions. At first, these changes were only evident in non-state higher education institutions, but since 2007, they have also occurred in the state vocational education segment. The market only grew in the part-time education and education by correspondence sectors, whereas the full-time education sector was shrinking. Two key factors-the 
demographic decline and the financial crisis, have caused a sharp decline in the public demand for vocational education. The wave of demographic decline arrived at higher education institutions at the moment the financial crisis began (Abankina \& Scherbakova, 2013).

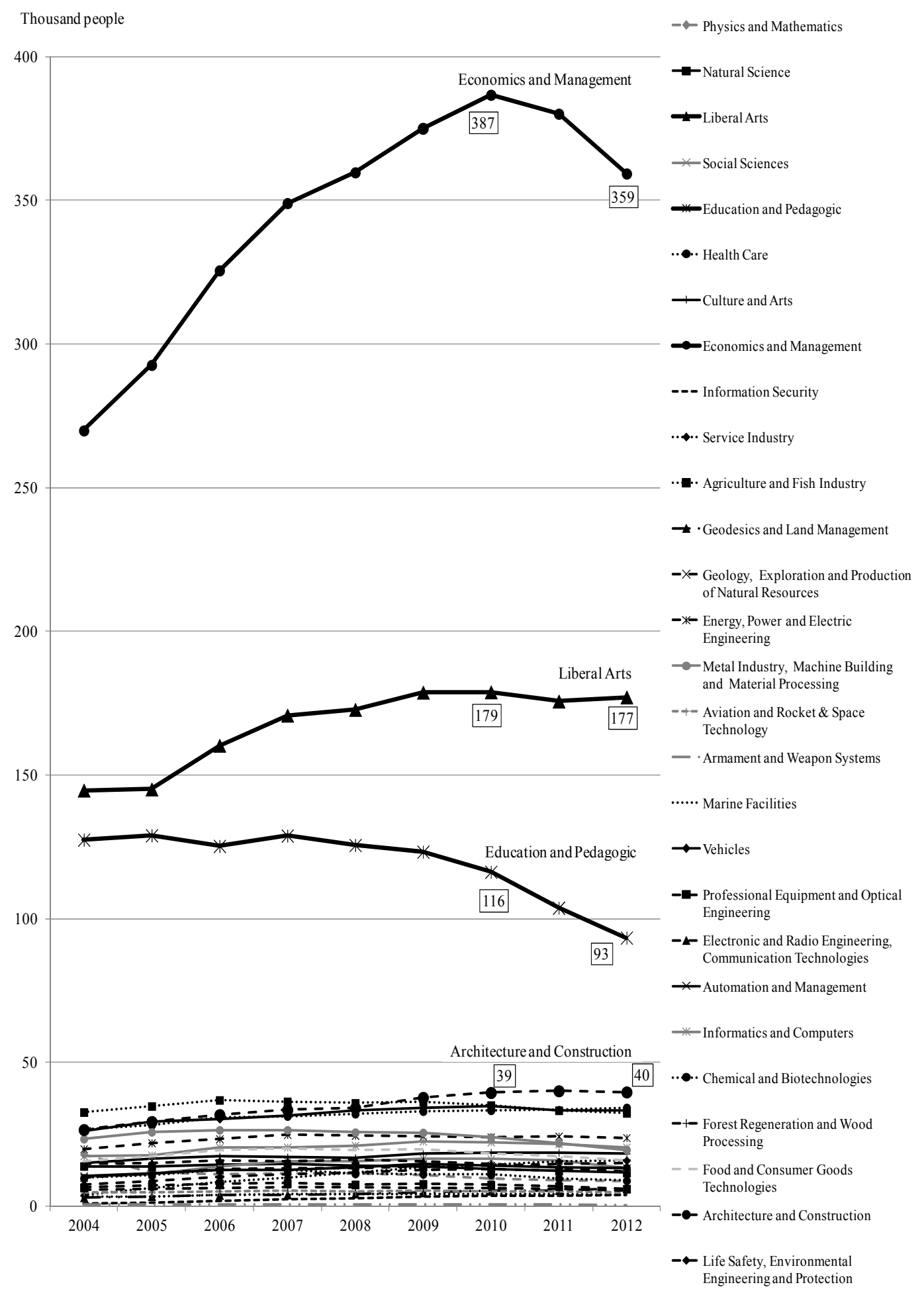

Figure 1. Number of graduates from state higher education institutions grouped by fields of study (28 groups of fields of study), in thousands of people. Source: Federal State Statistics Service (2013). 
The drop in universities' enrolment rates led to a decrease in the total number of students. During the 2011-2012 academic year, there were 6,490,000 students in higher education institutions in Russia, which is 560,000 less than the number in 2010-2011. This also caused a structural change in the modes of study: the number of full-time students dropped considerably and the number of part-time students increased by more than $16 \%$; the part-time mode of study became the predominant type (Filatova, I. Abankina, T. Abankina, \& Nikolayenko, 2012).

Beginning in 2008, a decline in consumer activity accompanied the change in public demand. After 2008, the amount of funds spent by the population on higher educational services significantly decreased as a result of the decrease in household income and the peculiarities of consumer expectations that were formed under the influence of excessive educational offerings from public and private higher education sectors.

Russia, as early as in 2000 , already had high rates of students per capita compared with other countries, only Finland and Korea's rates were higher. In 2010, the countries with the highest number of students in higher education per capita were Korea, the USA, and Russia. The comparative dynamics of the student rate per thousand is shown in Table 1.

The quoted data may be arranged into groups by the rate of growth of the number of students in various countries. Countries with excellent dynamics in this area, such as India and China, must be noted, but they initially had very low figures for student educational involvement. Therefore, even with such prominent "advancements" by these countries, they still lag far behind the other countries listed. However, they have progressed from a baseline many times lower than the average figures for other countries. For example, India has doubled the number of students in 10 years, and a breakthrough in China has resulted in approximately quadruple the number of students in 2010 compared with 2001.

Calling attention to the group of Eastern European countries (Hungary, Lithuania, Poland, Romania, and the Czech Republic), and the US, New Zealand, and Turkey, all had an initially high rate of students in 2000 whose numbers increased in a decade by $34 \%-37 \%$ (US and New Zealand), and sometimes doubled in number (Romania and Lithuania). Countries such as England, Switzerland, and Norway have been increasing the share of students much more gradually and smoothly. Rich countries, such as Sweden, Norway, the Netherlands, Austria, Australia, and Japan are distinguished by very stable and similar growth rates of the number of young people studying in universities.

Until 2009, the USA was behind Russia in the absolute number of students, however, in 2010, the USA surpassed Russia. If we compare the number of students with respective age cohorts of the population from 15 to 30 years old, in Russia, this category is shrinking following population decline. The USA does not suffer from the same change and, therefore, has the best prospects for the development of students' tertiary education. Nevertheless, Russia in the period 2000-2005 witnessed unprecedented growth in the number of students, which can be described as an "educational boom" in higher education.

The data provide evidence of an increase in the number of students in almost every country except for Russia, Finland, and Portugal, and, consequently, stronger demand for higher education. However, we were unable to identify analogues in other countries that confirmed processes similar to those in Russia (in the midst of declining demography and a demand for higher education) due to scale differences and structural changes.

Thus, for a long period of time, Russia was at a similar level as other countries with high rates of tertiary, secondary, professional, and higher education. Until now, Russia, in spite of demographic changes, is still a country with a large share of students. 
Table 1

Number of Students by Country (per 1,000 Citizens)

\begin{tabular}{|c|c|c|c|c|c|c|c|c|}
\hline Country & 2000 & 2005 & 2007 & 2008 & 2009 & 2010 & 2011 & 2012 \\
\hline Russia & 49 & 68 & 70 & 69 & 68 & 65 & 61 & 58 \\
\hline \multicolumn{9}{|l|}{ EU countries: } \\
\hline Austria & 33 & 30 & 32 & 35 & 38 & 43 & 44 & 46 \\
\hline Bulgaria & 33 & 32 & 35 & 36 & 38 & 40 & 40 & 40 \\
\hline Hungary & 30 & 44 & 44 & 42 & 41 & 40 & 39 & 39 \\
\hline Germany & - & - & - & - & - & - & 34 & 37 \\
\hline Greece & 39 & 58 & 54 & - & - & 57 & - & - \\
\hline Denmark & 36 & 44 & 44 & 43 & 44 & 45 & 48 & 51 \\
\hline Spain & 46 & 43 & 41 & 41 & 41 & 42 & 43 & 44 \\
\hline Italy & 31 & 35 & 35 & 35 & 35 & 34 & 34 & 33 \\
\hline Lithuania & 35 & 61 & 64 & 67 & 70 & 67 & 63 & 59 \\
\hline The Netherlands & 31 & 36 & 37 & 38 & 38 & 40 & 48 & 49 \\
\hline Poland & 42 & 56 & 57 & 58 & 58 & 58 & 56 & 54 \\
\hline Portugal & 37 & 37 & 36 & 37 & 36 & 37 & - & 38 \\
\hline Romania & 21 & 34 & 43 & 49 & 51 & 47 & 41 & - \\
\hline United Kingdom (Great Britain) & 35 & 39 & 40 & 39 & 41 & 41 & 41 & 41 \\
\hline Finland & 53 & 60 & 60 & 60 & 57 & 58 & 59 & 59 \\
\hline France & 35 & 37 & 36 & 36 & 36 & 37 & 37 & 37 \\
\hline Czech Republic & 25 & 34 & 36 & 39 & 41 & 43 & 43 & 42 \\
\hline Sweden & 39 & 49 & 47 & 46 & 47 & 50 & 51 & 50 \\
\hline \multicolumn{9}{|l|}{ Other countries: } \\
\hline Australia & 45 & 51 & 52 & 53 & 56 & 59 & 60 & 61 \\
\hline Argentina & 44 & - & 39 & - & - & - & - & - \\
\hline India & 9 & 11 & 13 & 15 & 16 & 18 & 22 & 24 \\
\hline China & 6 & 16 & 19 & 20 & 22 & 23 & 23 & 24 \\
\hline Mexico & 20 & 22 & 23 & 23 & 24 & 25 & 26 & 27 \\
\hline New Zealand & 45 & 60 & 59 & 59 & 63 & 63 & 61 & 60 \\
\hline Norway & 43 & 48 & 47 & 46 & 47 & 48 & 48 & 50 \\
\hline Republic of Korea & 66 & 69 & 68 & 68 & 68 & 69 & 70 & 70 \\
\hline USA & 47 & 60 & 60 & 61 & 64 & 67 & 69 & 68 \\
\hline Turkey & 25 & 32 & 36 & 37 & 42 & 50 & 53 & 60 \\
\hline Switzerland & 22 & 28 & 29 & 30 & 31 & 33 & 34 & 35 \\
\hline Japan & 32 & 33 & 33 & 32 & 32 & 31 & 32 & 32 \\
\hline
\end{tabular}

Note. Source: Federal State Statistics Service (2013).

\section{Data, Variables, and Methods}

To confirm conclusions regarding the public demand for higher education provided in this paper, the authors employ an econometric analysis of the impact of economic factors on receiving a university degree in Russia and in Moscow. Research using regression analysis for the evaluation of achievements in the area of higher education and the influence of prior learning on the economic growth rate has been conducted 
throughout the world (Acemoglu, 1996; Barro, 1991; Becker, Murphy, \& Tamura, 1990; Benhabib \& Spiegel, 1994; Bratti \& Leombruni, 2014; Cunha \& Miller, 2014; O’Hear \& MacDonald, 1995; Romer, 1990; Solow, 1957). These studies make it possible to describe a mechanism of socially increasing the return on investments in human capital, to evaluate the contribution to economic growth using exogenous factors of technological advancement, and to expose the impact of human capital on economic development in crisis situations. The economic return on education is analysed in many papers, studying the evaluation of using the meta-analysis method (Flabbi, Paternostro, \& Tiongson, 2008; Psacharopoulos \& Patrinos, 2004). The research confirms the positive macroeconomic impact of education on economic growth observed when an average education level is low, whereas in cases with a longer average period of education, the impact of education on economic growth becomes lower (Sianesi \& Van Reenen, 2003). Certain Russian sources use regression analysis to evaluate the interplay of cumulative and accumulative (i.e., produced by the education system) human capital and their influence on the labour market, the amplitude of innovation processes and economic growth (Kapeliushnikov, 2012; Kazantsev \& Nikitina, 2004; Koritsky, 2010; Oschepkov, 2010; Russian employee: Education, profession, qualification, 2011).

To demonstrate the factors influencing the variation of demand for higher education, the authors examined the correlation of student enrolment in particular Russian regions with the cumulative human capital and other explanatory variables for the period 2001-2010. For independent variables, they used capital investment, the deposit amount by individuals in banking institutions, the share of employed individuals with a university degree and the number of secondary school graduates (less evening school graduates) with a secondary (full) education certificate. A non-linear regression for the evaluated parameters, transformed from a logarithm, provided the best results in evaluating the statistical significance of the initial data:

$$
Y_{i}^{t}=A+\alpha_{1} X_{1 i}^{t}+\alpha_{2} X_{2 i}^{t}+\alpha_{3} X_{3 i}^{t}+\alpha_{4} X_{4 i}^{t}
$$

Where $Y_{i}^{t}=\ln y_{i}^{t}, A=\ln a, X_{1 i}^{t}=\ln x_{1 i}^{t}, X_{2 i}^{t}=\ln x_{2 i}^{t}, X_{3 i}^{t}=\ln x_{3 i}^{t}$, and $X_{4 i}^{t}=\ln x_{4 i}^{t} ; y_{i}^{t}$ is the enrolment rate of higher vocational education institutions in region $i$ in year $t ; a$ is a constant; $x_{1 i}^{t}$ is the share of employed individuals with a university degree in the economics of region $i$ in year $t ; x_{2 i}^{t}$ is the number of secondary school graduates (less evening school graduates) with a secondary (full) education certificate in region $i$ in year $t ; x_{3 i}^{t}$ is the capital investments per capita in region $i$ in year $t ; x_{4 i}^{t}$ is the deposit amount by individuals with banking institutions per capita in region $i$ in year $t$; and $\alpha_{j}$ is the elasticity coefficient of independent variables $(j$ $=1, \ldots, 4)$.

The calculations are based on statistical data for 79 Russian regions, except the Chukotka Autonomous Area and the Chechen Republic (before 2006) because of a lack of required information.

Regional differences of explanatory variables by level of capital investments may be explained by the reserves of cumulative factors of production - physical capital. The deposits by individuals with banking institutions may represent investments into human capital. The number of employed individuals with a university degree and secondary school graduates may be classified as the cumulative and emerging human capital in the region.

Here we review the demand for higher education in the largest Russian metropolises-Moscow and Saint Petersburg. As a characteristic of the intensity of investments into human capital, we use the student enrolment rate to find a correlation with other economic indicators from 2001 to 2010. The independent variables are as follows: the share of employed individuals with university degrees in the economics of the regions and the 
number of schoolchildren attending state-owned institutions (less evening schools). These factors characterize cumulative human capital and the level and rate of its accumulation. Additional variables include average monthly salary, which may explain the availability of investments into human capital; gross regional product, which permits an evaluation of the impact of physical capital on higher education; and slack variables, as evidence of the influence of metropolises on the demand for higher education in the major Russian cities. The calculations are based on statistical data for 78 Russian regions, except the Chukotka Autonomous Area and the Chechen Republic because of a lack of required information.

Linear regression equations provided the best results in the evaluation of the statistical significance of the data:

$$
y_{i}^{t}=a_{0}+a_{1} x_{1 i}^{t}+a_{2} x_{2 i}^{t}+a_{3} x_{3 i}^{t}+a_{4} x_{4 i}^{t}+a_{5} x_{5}
$$

Where $y_{i}^{t}$ is the enrolment rate of higher vocational education institutions in region $i$ in year $t ; a_{0}$ is a constant; $x_{1 i}^{t}$ is the share of employed individuals with a university degree in the economics of region $i$ in year $t$; $x_{2 i}^{t}$ is the number of schoolchildren attending state-owned institutions (less evening schools) in region $i$ in year $t$; $x_{3 i}^{t}$ is the gross regional product per capita in region $i$ in year $t ; x_{4 i}^{t}$ is the average monthly salary in region $i$ in year $t ; x_{5}$ is the slack variables characterizing the Moscow and Saint Petersburg metropolises; and $a_{j}$ is the coefficients of independent variables $(j=1, \ldots, 5)$.

\section{Empirical Results}

The determination coefficients (R-squared) of the regression equation (1) throughout the research period are rather high and range from $89 \%$ to $93 \%$. The confidence probability numbers are $95 \%$. The elasticity coefficient for financial deposits by individuals shows a clear upward trend from $0.096 \%$ in 2001 to $0.481 \%$ in 2010, with a slight decrease of coefficients clearly marking the period before the global financial crisis in 2005-2007 (see Table 2). The liquidity of deposits and the level of a population's purchasing power allowing for a quick reaction to educational offers are noted. It is evident that the growth in deposits of a population has a positive impact on the urge of young people to get a university diploma. The higher the amount of a population's savings assuring future financial stability, the higher the probability that the parents would use the savings as an investment in higher education for their children. Thus, investment in human capital represented by the independent variable of the amount of deposits by individuals with banking institutions proves to be the most important factor influencing the enrolment rate at higher education institutions.

Coefficients of variables characterizing capital investments are statistically significant only for the third part of the period under consideration and do not have a positive impact on student enrolment, especially during times of financial crisis. To build the industrial capacity of regions, it is necessary to accumulate capital investments, which in turn, encourages an increase in the productive power of regions and, consequently, the liquidation of a deficit of blue-collar labour resources and a lower unemployment rate. This probably explains the absence of the positive impact of volumes of capital investments on the enrolment rate of higher education institutions. Another interpretation of this fact is the insufficient capital investments for the renewal of capital assets, which deteriorate and become obsolete with time.

The elasticity coefficients of the number of employed individuals with a university degree variable grew significantly in the financial pre-crisis period - from $0.46 \%$ to $0.84 \%$ during $2001-2004$, then dropped in 2005 (to $0.32 \%$ ) and subsequently increased slightly until 2007 . The later period, marked by the financial crisis, is characterized by a sharp decrease in the elasticity coefficient and a negative impact on the enrolment rate of 
higher education institutions. In other words, human capital, represented by the number of employed individuals with a university degree, proved to be the most significant factor positively influencing the number of prospective students applying to universities, but only before 2004. Subsequent changes in the country caused by the financial crisis, the demographic decline and countrywide introduction of a Unified State Exam (USE) in the area of higher education, have resulted in the influence of cumulative human capital on the enrolment rate of higher education institutions.

The explanatory variable - the number of secondary school graduates, is statistically significant and positively influences the enrolment rate of higher education institutions, whereas the elasticity coefficients of this variable at the beginning of the financial crisis (2008) had dramatically increased. The dynamics of this coefficient exhibits a slight annual decrease (from $1.34 \%$ in 2001 to $1.01 \%$ in 2010), which is explained by changes in the population structure caused by a demographic decline. Therefore, the human capital represented by this variable proves to be another material factor, along with the amount of deposits by a population, positively influencing the dependent variable. The beta-coefficient $\beta_{\mathrm{j}}$ shows the standard deviation value of the dependent variable $Y^{t}$ with changes to the independent variable $X_{j}^{t}$ by its standard deviation value.

The determination coefficients (R-squared) of the regression equation (2) are rather high and range from $84 \%$ to $90 \%$. The explanatory variable - the number of schoolchildren is statistically significant and positively influences the enrolment rate of higher education institutions (see Table 3). The dynamics of the unstandardized coefficient of this variable shows a slight annual decrease, which became more apparent in the last four years (a reduction from 0.11 in 2007 to 0.09 in 2010). The elasticity coefficient also confirms a positive impact on the acceptance of students, but with a decreasing trajectory (form $0.94 \%$ in 2001 to $0.87 \%$ in 2010), which is explained by changes in the population structure caused by a demographic decline. Therefore, human capital, represented by this factor, positively influences the dependent variable.

The coefficients of variables characterizing salaries proved to be statistically significant for the first half of the period under consideration. Moreover, this variable had a negative impact on the student enrolment rate throughout the period under consideration. However, the dynamics of the elasticity coefficient of this variable for 2001-2010 testifies to its increase. Similar cause and effect relationships are noted in Russian research papers; therefore, the negative impact is explained by the fact that the salary amount is closely connected to the amount of "lost earnings" in the course of attaining a full-time course university diploma, as students generally choose not to work during the course of studies (Koritsky, 2010).

The elasticity coefficients of the number of employed individuals with a university degree variable decreased from $0.98 \%$ in 2001 to $0.15 \%$ in 2010 , with the fastest decline during the $2008-2010$ financial crisis period. Thus, the changes caused by financial uncertainty reduced the impact of cumulative human capital on the enrolment rate of higher education institutions.

The independent variable characterizing the gross regional product had a significant impact on individuals, obtaining a university degree in 2003 , and the elasticity coefficient of this factor was $0.79 \%$. However, after 2004 (when the elasticity coefficient dropped to $0.37 \%$ ), the cumulative physical capital had lost its advantage of influencing the accumulation of new knowledge among young people, and during 2008-2010, the coefficients of this variable proved to be statistically insignificant. This is evidence of the effect of the world financial crisis on the development of specific industries, and of the higher education sector in this particular case. 
Table 2

Coefficients Explaining the Correlation of the Student Enrolment Rate in Russia

\begin{tabular}{|c|c|c|c|c|c|c|c|c|c|c|c|}
\hline Variable & Coefficient & 2001 & 2002 & 2003 & 2004 & 2005 & 2006 & 2007 & 2008 & 2009 & 2010 \\
\hline \multirow{3}{*}{$\begin{array}{l}\text { Employed with } \\
\text { university degrees }\end{array}$} & Constant $a$ & $\begin{array}{l}-2.494^{* * *} \\
(0.601)\end{array}$ & $\begin{array}{l}-1.633^{* * *} \\
(0.484)\end{array}$ & $\begin{array}{l}-2.721^{* * *} \\
(0.502)\end{array}$ & $\begin{array}{l}-2.875^{* * *} \\
(0.483)\end{array}$ & $\begin{array}{l}-1.371^{* * *} \\
(0.508)\end{array}$ & $\begin{array}{l}-1.495^{* * *} \\
(0.550)\end{array}$ & $\begin{array}{l}-1.396^{*} \\
(0.638)\end{array}$ & $\begin{array}{l}0.497 \\
(0.668)\end{array}$ & $\begin{array}{l}-0.329 \\
(0.580)\end{array}$ & $\begin{array}{l}-0.003 \\
(0.738)\end{array}$ \\
\hline & $\begin{array}{l}\text { Elasticity } \\
\text { coefficient } \alpha_{1}\end{array}$ & $\begin{array}{l}0.643^{* * *} \\
(0.194)\end{array}$ & $\begin{array}{l}0.459^{* * *} \\
(0.163)\end{array}$ & $\begin{array}{l}0.793^{* * *} \\
(0.159)\end{array}$ & $\begin{array}{l}0.843^{* * *} \\
(0.153)\end{array}$ & $\begin{array}{l}0.326^{* *} \\
(0.158)\end{array}$ & $\begin{array}{l}0.334^{* *} \\
(0.161)\end{array}$ & $\begin{array}{l}0.334^{*} \\
(0.192)\end{array}$ & $\begin{array}{l}-0.289 \\
(0.190)\end{array}$ & $\begin{array}{l}0.027 \\
(0.166)\end{array}$ & $\begin{array}{l}-0.078 \\
(0.218)\end{array}$ \\
\hline & Beta-coefficient $\beta_{1}$ & $0.131^{* * *}$ & $0.099^{* * *}$ & $0.161^{* * *}$ & $0.171^{* * *}$ & $0.068^{* *}$ & $0.070^{* *}$ & $0.065^{*}$ & -0.056 & 0.005 & -0.014 \\
\hline \multirow[t]{2}{*}{$\begin{array}{l}\text { Secondary school } \\
\text { graduates }\end{array}$} & Elasticity coefficient $\alpha_{2}$ & $\begin{array}{l}1.134^{* * *} \\
(0.061)\end{array}$ & $\begin{array}{l}1.039^{* * *} \\
(0.051)\end{array}$ & $\begin{array}{l}1.071^{* * *} \\
(0.046)\end{array}$ & $\begin{array}{l}1.047^{* * *} \\
(0.043)\end{array}$ & $\begin{array}{l}1.042^{* * *} \\
(0.042)\end{array}$ & $\begin{array}{l}1.058^{* * *} \\
(0.042)\end{array}$ & $\begin{array}{l}1.024^{* * *} \\
(0.048)\end{array}$ & $\begin{array}{l}1.094^{* * *} \\
(0.048)\end{array}$ & $\begin{array}{l}1.025^{* * *} \\
(0.043)\end{array}$ & $\begin{array}{l}1.010^{* * *} \\
(0.049)\end{array}$ \\
\hline & Beta-coefficient $\beta_{2}$ & $0.865^{* * *}$ & $0.847^{* * *}$ & $0.850^{* * *}$ & $0.846^{* * *}$ & $0.856^{* * *}$ & $0.865^{* * *}$ & $0.841^{* * *}$ & $0.861^{* * *}$ & $0.830^{* * *}$ & $0.824^{* * *}$ \\
\hline \multirow[t]{2}{*}{ Capital investments } & Elasticity coefficient $\alpha_{3}$ & $\begin{array}{l}-0.020 \\
(0.063)\end{array}$ & $\begin{array}{l}-0.034 \\
(0.057)\end{array}$ & $\begin{array}{l}-0.065 \\
(0.058)\end{array}$ & $\begin{array}{l}-0.083^{*} \\
(0.050)\end{array}$ & $\begin{array}{l}-0.140^{* *} \\
(0.065)\end{array}$ & $\begin{array}{l}-0.095^{*} \\
(0.063)\end{array}$ & $\begin{array}{l}-0.080 \\
(0.075)\end{array}$ & $\begin{array}{l}-0.154^{* *} \\
(0.075)\end{array}$ & $\begin{array}{l}-0.202^{* * *} \\
(0.064)\end{array}$ & $\begin{array}{l}-0.225^{* * *} \\
(0.075)\end{array}$ \\
\hline & Beta-coefficient $\beta_{3}$ & -0.013 & -0.023 & -0.042 & $-0.060^{*}$ & $-0.090^{* *}$ & $-0.061^{*}$ & -0.046 & $-0.091^{* *}$ & $-0.124^{* * *}$ & $-0.136^{* * *}$ \\
\hline \multirow[t]{5}{*}{$\begin{array}{l}\text { Amounts of deposits } \\
\text { of population }\end{array}$} & Elasticity coefficient $\alpha_{4}$ & $\begin{array}{l}0.096^{*} \\
(0.045)\end{array}$ & $\begin{array}{l}0.142^{* *} \\
(0.039)\end{array}$ & $\begin{array}{l}0.160^{* * *} \\
(0.034)\end{array}$ & $\begin{array}{l}0.181^{* * *} \\
(0.035)\end{array}$ & $\begin{array}{l}0.333^{* * *} \\
(0.065)\end{array}$ & $\begin{array}{l}0.310^{* * *} \\
(0.054)\end{array}$ & $\begin{array}{l}0.301^{* * *} \\
(0.054)\end{array}$ & $\begin{array}{l}0.390^{* * *} \\
(0.057)\end{array}$ & $\begin{array}{l}0.458^{* * *} \\
(0.055)\end{array}$ & $\begin{array}{l}0.481^{* * *} \\
(0.066)\end{array}$ \\
\hline & Beta-coefficient $\beta_{4}$ & $0.101^{*}$ & $0.158^{* *}$ & $0.196^{* * *}$ & $0.211^{* * *}$ & $0.228^{* * *}$ & $0.241^{* * *}$ & $0.249^{* * *}$ & $0.304^{* * *}$ & $0.338^{* * *}$ & $0.346^{* * *}$ \\
\hline & R-squared & 0.889 & 0.914 & 0.925 & 0.933 & 0.930 & 0.924 & 0.899 & 0.908 & 0.921 & 0.895 \\
\hline & F-statistics & 145.6 & 194.0 & 226.0 & 256.0 & 242.7 & 223.4 & 164.2 & 182.0 & 215.2 & 157.1 \\
\hline & Number of regions & 78 & 78 & 78 & 78 & 78 & 79 & 79 & 79 & 79 & 79 \\
\hline
\end{tabular}

Notes. Robust standard errors are reported in parentheses; ${ }^{*}$ statistical significance at $10 \%,{ }^{* *}$ statistical significance at $5 \%$, and ${ }^{* * *}$ statistical significance at $1 \%$. 
Table 3

Coefficients Explaining the Correlation of the Student Enrolment Rate in Moscow and Saint Petersburg

\begin{tabular}{|c|c|c|c|c|c|c|c|c|c|c|c|}
\hline Variable & Coefficient & 2001 & 2002 & 2003 & 2004 & 2005 & 2006 & 2007 & 2008 & 2009 & 2010 \\
\hline \multirow{4}{*}{$\begin{array}{l}\text { Employed with } \\
\text { university degrees }\end{array}$} & Constant $a_{0}$ & $\begin{array}{l}-16.760^{* *} \\
(8.451)\end{array}$ & $\begin{array}{l}-3.230 \\
(7.112)\end{array}$ & $\begin{array}{l}-15.330 \\
(12.590)\end{array}$ & $\begin{array}{l}-18.070 \\
(11.222)\end{array}$ & $\begin{array}{l}-9.503 \\
(9.321)\end{array}$ & $\begin{array}{l}-11.352 \\
(7.951)\end{array}$ & $\begin{array}{l}-9.380 \\
(9.659)\end{array}$ & $\begin{array}{l}-3.407 \\
(8.423)\end{array}$ & $\begin{array}{l}-3.768 \\
(7.057)\end{array}$ & $\begin{array}{l}-1.523 \\
(7.016)\end{array}$ \\
\hline & Coefficient $a_{1}$ & $\begin{array}{l}0.872^{* *} \\
(0.357)\end{array}$ & $\begin{array}{l}0.306 \\
(0.295)\end{array}$ & $\begin{array}{l}0.822^{*} \\
(0.499)\end{array}$ & $\begin{array}{l}0.652 \\
(0.418)\end{array}$ & $\begin{array}{l}0.384 \\
(0.361)\end{array}$ & $\begin{array}{l}0.565^{* *} \\
(0.273)\end{array}$ & $\begin{array}{l}0.480 \\
(0.333)\end{array}$ & $\begin{array}{l}0.252 \\
(0.297)\end{array}$ & $\begin{array}{l}0.148 \\
(0.249)\end{array}$ & $\begin{array}{l}0.098 \\
(0.264)\end{array}$ \\
\hline & Elasticity coefficient $\alpha_{1}$ & $0.984^{* *}$ & 0.334 & $0.835^{*}$ & 0.676 & 0.405 & $0.620^{* *}$ & 0.543 & 0.297 & 0.194 & 0.145 \\
\hline & Beta-coefficient $\beta_{1}$ & $0.126^{* *}$ & 0.052 & $0.101^{*}$ & 0.085 & 0.058 & $0.098^{* *}$ & 0.073 & 0.043 & 0.028 & 0.019 \\
\hline \multirow[t]{3}{*}{ Schoolchildren } & Coefficient $a_{2}$ & $\begin{array}{l}0.071^{* * *} \\
(0.009)\end{array}$ & $\begin{array}{l}0.072^{* * *} \\
(0.008)\end{array}$ & $\begin{array}{l}0.086^{* * *} \\
(0.014)\end{array}$ & $\begin{array}{l}0.101^{* * *} \\
(0.012)\end{array}$ & $\begin{array}{l}0.101^{* * *} \\
(0.011)\end{array}$ & $\begin{array}{l}0.106^{* * *} \\
(0.011)\end{array}$ & $\begin{array}{l}0.112^{* * *} \\
(0.012)\end{array}$ & $\begin{array}{l}0.109^{* * *} \\
(0.012)\end{array}$ & $\begin{array}{l}0.103^{* * *} \\
(0.009)\end{array}$ & $\begin{array}{l}0.094^{* * *} \\
(0.008)\end{array}$ \\
\hline & Elasticity coefficient $\alpha_{2}$ & $0.938^{* * *}$ & $0.870^{* * *}$ & $0.898^{* * *}$ & $0.971^{* * *}$ & $0.921^{* * *}$ & $0.902^{* * *}$ & $0.901^{* * *}$ & $0.876^{* * *}$ & $0.874^{* * *}$ & $0.876^{* * *}$ \\
\hline & Beta-coefficient $\beta_{2}$ & $0.400^{* * *}$ & $0.438^{* * *}$ & $0.365^{* * *}$ & $0.431^{* * *}$ & $0.452^{* * *}$ & $0.455^{* * *}$ & $0.465^{* * *}$ & $0.471^{* * *}$ & $0.493^{* * *}$ & $0.499^{* * *}$ \\
\hline \multirow[t]{3}{*}{$\begin{array}{l}\text { Gross regional } \\
\text { product }\end{array}$} & Coefficient $a_{3}$ & $\begin{array}{l}0.317^{* * *} \\
(0.108)\end{array}$ & $\begin{array}{l}0.234^{* * *} \\
(0.068)\end{array}$ & $\begin{array}{l}0.257^{* * *} \\
(0.089)\end{array}$ & $\begin{array}{l}0.052 \\
(0.045)\end{array}$ & $\begin{array}{l}0.056^{*} \\
(0.032)\end{array}$ & $\begin{array}{l}0.065^{* *} \\
(0.027)\end{array}$ & $\begin{array}{l}0.056^{* *} \\
(0.025)\end{array}$ & $\begin{array}{l}0.045^{* *} \\
(0.019)\end{array}$ & $\begin{array}{l}0.020 \\
(0.017)\end{array}$ & $\begin{array}{l}0.015 \\
(0.012)\end{array}$ \\
\hline & Elasticity coefficient $\alpha_{3}$ & $0.737^{* * *}$ & $0.639^{* * *}$ & $0.791^{* * *}$ & 0.202 & $0.261^{*}$ & $0.373^{* *}$ & $0.397^{* *}$ & $0.395^{* *}$ & 0.183 & 0.182 \\
\hline & Beta-coefficient $\beta_{3}$ & $0.310^{* * *}$ & $0.307^{* * *}$ & $0.308^{* * *}$ & 0.097 & $0.140^{*}$ & $0.194^{* *}$ & $0.199^{* *}$ & $0.194^{* *}$ & 0.091 & 0.093 \\
\hline \multirow[t]{3}{*}{$\begin{array}{l}\text { Average monthly } \\
\text { salary }\end{array}$} & Coefficient $a_{4}$ & $\begin{array}{l}-0.006^{* *} \\
(0.002)\end{array}$ & $\begin{array}{l}-0.004^{* * *} \\
(0.001)\end{array}$ & $\begin{array}{l}-0.004^{* *} \\
(0.02)\end{array}$ & $\begin{array}{l}-0.001 \\
(0.001)\end{array}$ & $\begin{array}{l}-0.001 \\
(0.0008)\end{array}$ & $\begin{array}{l}-0.001 \\
(0.0007)\end{array}$ & $\begin{array}{l}-0.001 \\
(0.0007)\end{array}$ & $\begin{array}{l}-0.001^{*} \\
(0.0005)\end{array}$ & $\begin{array}{l}-0.0002 \\
(0.0004)\end{array}$ & $\begin{array}{l}-0.0003 \\
(0.0003)\end{array}$ \\
\hline & Elasticity coefficient $\alpha_{4}$ & $-0.914^{* *}$ & $-0.804^{* * *}$ & $-0.955^{* *}$ & -0.160 & -0.279 & -0.494 & -0.538 & $-0.540^{*}$ & -0.197 & -0.256 \\
\hline & Beta-coefficient $\beta_{4}$ & $-0.243^{* *}$ & $-0.228^{* * *}$ & $-0.209^{* *}$ & -0.036 & -0.068 & -0.119 & -0.126 & $-0.128^{*}$ & -0.048 & -0.062 \\
\hline \multirow[t]{6}{*}{ Slack variables } & Coefficient $a_{5}$ & $\begin{array}{l}110.13^{* * *} \\
(11.703)\end{array}$ & $\begin{array}{l}96.50^{* * *} \\
(9.792)\end{array}$ & $\begin{array}{l}131.78^{* * *} \\
(16.766)\end{array}$ & $\begin{array}{l}134.18^{* * *} \\
(13.976)\end{array}$ & $\begin{array}{l}118.37^{* * *} \\
(12.114)\end{array}$ & $\begin{array}{l}112.06^{* * *} \\
(10.981)\end{array}$ & $\begin{array}{l}112.15^{* * *} \\
(11.561)\end{array}$ & $\begin{array}{l}110.07^{* * *} \\
(10.894)\end{array}$ & $\begin{array}{l}104.47^{* * *} \\
(9.080)\end{array}$ & $\begin{array}{l}96.22^{* * *} \\
(8.528)\end{array}$ \\
\hline & Elasticity coefficient $\alpha_{5}$ & $0.151^{* * *}$ & $0.129^{* * *}$ & $0.161^{* * *}$ & $0.162^{* * *}$ & $0.145^{* * *}$ & $0.136^{* * *}$ & $0.134^{* * *}$ & $0.135^{* * *}$ & $0.136^{* * *}$ & $0.138^{* * *}$ \\
\hline & Beta-coefficient $\beta_{5}$ & $0.529^{* * *}$ & $0.528^{* * *}$ & $0.529^{* * *}$ & $0.575^{* * *}$ & $0.561^{* * *}$ & $0.536^{* * *}$ & $0.534^{* * *}$ & $0.552^{* * *}$ & $0.577^{* * *}$ & $0.583^{* * *}$ \\
\hline & R-squared & 0.879 & 0.888 & 0.837 & 0.859 & 0.876 & 0.884 & 0.878 & 0.891 & 0.896 & 0.901 \\
\hline & F-statistics & 104.62 & 113.65 & 73.81 & 87.72 & 101.46 & 109.48 & 103.57 & 117.38 & 124.44 & 131.66 \\
\hline & Number of regions & 78 & 78 & 78 & 78 & 78 & 78 & 78 & 78 & 78 & 78 \\
\hline
\end{tabular}

Notes. Robust standard errors are reported in parentheses; ${ }^{*}$ statistical significance at $10 \%,{ }^{* *}$ statistical significance at $5 \%$, and ${ }^{* * *}$ statistical significance at $1 \%$. 
Slack variables, characterizing the metropolises of Moscow and Saint Petersburg, are statistically significant throughout the period being considered and are positively correlated to the dependent variable, which is characteristic of metropolises with an unusual concentration of advanced technology and cultural heritage, and high educational standards based on fundamental and applied research. Young people are drawn to these metropolises to attain new knowledge. However, the impact of this factor decreases over time, as the unstandardized coefficient of this variable demonstrates, dropping from 110.3 in 2001 to 96.2 in 2010. The maximum value of the coefficient (134.2) falls in 2004, a year marked by extensive growth of public demand on the higher vocational education market in Moscow. Further reduction of the coefficients confirms that their impact on obtaining a university degree in Moscow and Saint Petersburg becomes lower. The coefficients explaining the correlation of student enrolment rates, the number of employed individuals with university degrees, the number of schoolchildren, the gross regional product and salaries in Moscow and Saint Petersburg are shown in Table 3.

At the beginning of the global financial crisis, it appeared that the higher education institutions in Moscow would be in the strongest position to survive the crisis and the demographic decline. On the one hand, they are the country's leading universities with a strong reputation among entrants and their parents. And, on the other hand, the financial position of families in Moscow was relatively stable in comparison with other areas of Russia, and unemployment in Moscow was lower than elsewhere. However, the situation has developed quite differently. Regional institutions of higher education and even those in Saint Petersburg have turned out to be less sensitive to the changing trends of the education market and, consequently, did not experience a significant drop in enrolment numbers. During the financial crisis, Moscow was unable to attract more entrants from other regions to compensate for the reduction in graduates from Moscow schools. Thus, the influence of the financial crisis and the demographic decline was more noticeable in Moscow than in other Russian cities.

Empirical studies show that the enrolment rate is heavily reliant on the financial solvency of a population. High-income households give higher preference to higher education services. However, in times of financial crisis, it is this high-income part of the population that cuts its expenses on higher education. These families experienced instability and began to decrease their expenses for higher education systems. Parents were unable to fully compensate the university education of their children from their income and savings. This had an adverse effect on lower income families' access to higher education.

The student body potential — the number of secondary school graduates is statistically significant and has a positive effect on the enrolment at universities. A positive impact of the accumulated human capital (the number of individuals employed with university degrees in the regional economy) on the increase in public demand was observed up to 2007. Further saturation of the labour market by specialists in popular specializations (economists, lawyers, teachers, etc.) negatively affected the enrolment at universities that is also associated with the aftermath of the financial crisis.

The physical capital of the regions does not have a positive impact on the university enrolment rates (investments into fixed capital), being primarily aimed at the creation of future jobs in the regions and characterized by a low level of financial resources for scientific and innovative industries that promote the development of a highly qualified specialists market.

\section{Discussion and Conclusions}

The economic stability of households is of primary importance for raising the public demand for higher 
education. The great potential for furthering the development of higher education and, accordingly, a higher enrolment rate lies in the number of secondary school graduates, which positively influences the increase in public demand. Allocations to fixed capital may be viewed as investment projects by the enterprises in the regions, which create and develop the foundation for future university graduate jobs. Nevertheless, this factor does not have a positive influence on public demand and, consequently, does not promote highly skilled potential in the region. Today, the saturation of the labour market by specialists in popular specializations (economists, lawyers, teachers, etc.) is not considered to be a positive but a negative factor influencing a decline in student enrolment at universities. One of the possible methods for changing this trend could be a proper restructuring that allows for the optimization of resources in the context of a shrinking higher education market.

Empirical studies confirm three consecutive stages in changing public demand. The first stage is characterized by increasing public demand; this stage coincides with the "educational boom" period (1995-2005).

The second stage is characterized by a sharp decline in public demand and the transition to a market with a "shrinking" demand for higher education services (2006-2010). This period is marked by market oversaturation by specialists in popular specializations and the inability of high-income groups to invest in higher education at the same level. The social and economic status of the regions requires the creation of new jobs for university graduates that promotes trust among the people in the practicability of investments for their children's future.

The third stage is aimed at maintaining public demand at the same level and further stimulating its increase (since 2011). This stage involves the restructuring of higher (and secondary) education institutions and an active process of mergers and acquisitions of universities, but there is no public consensus on the possible results of these processes, as their effects and advantages may not become evident until many years into the future.

Analysis of the trends in public demand and the detection of patterns that are attributed not only to the Russian system of higher education confirm the need for a transition to the structural optimization of educational, material, technical, financial, and intellectual resources.

The integration processes in the field of higher education that are related to the restructuring of education launched in 2011 should improve education quality and ensure the competitiveness of university graduates in the labour market by combining financial, technological, and intellectual resources. To maintain consumer demand, vocational education institutions should take the initiative and develop advanced educational programmes. The higher education institutions that are currently in the best position are those with a multidisciplinary approach and diversified strategy. They are able to recruit strong students and secure the enrolment of both the state-subsidized and tuition-paying students. By using the advantages of their independence and competent asset management, these institutions maintain their competitiveness in the market of educational services and begin actively acquiring the weaker institutions.

The re-structuring process will be uneven in both dynamics and territorial aspect. The group of regional universities under threat of acquisition may include educational institutions that had a strong economic position during times of economic growth but during the financial crisis, began losing their tuition-paying students, lacking effective management technologies and established relationships with employers.

\section{References}

Abankina, I., Abankina, T., Filatova, L., Nikolayenko, E., \& Seroshtan, E. (2012). The effects of reform on the performance of higher education institutions. Journal of Applied Research in Higher Education, 4(1), 23-41. 
Abankina, I., \& Scherbakova, I. (2013). Russian higher education reforms and the Bologna Process. Journal of the European Higher Education Area, 3, 3-25.

Acemoglu, D. (1996). A microfoundation for social increasing returns in human capital accumulation. Quarterly Journal of Economics, 111(3), 779-804.

Araya, D., \& Peters, M. A. (2010). Education in the creative economy: Knowledge and learning in the age of innovation. New York: Peter Lang Publishing, Inc.

Barro, R. J. (1991). Economic growth in a cross section of countries. Quarterly Journal of Economics, 106(2), 407-443.

Becker, G. S., Murphy, K. M., \& Tamura, R. (1990). Human capital, fertility and economic growth. Journal of Political Economy, 98(5), 12-37.

Benhabib, J., \& Spiegel, M. M. (1994). The role of human capital in economic development: Evidence from aggregate cross-country data. Journal of Monetary Economics, 34(2), 143-173.

Berger, M. C., \& Kostal, T. (2002). Financial resources, regulation, and enrollment in US public higher education. Economics of Education Review, 21(2), 101-110.

Bratti, M., \& Leombruni, R. (2014). Local human capital externalities and wages at the firm level: Evidence from Italian manufacturing. Economics of Education Review, 41, 161-175.

Bruckmeier, K., \& Wigger, B. U. (2014). The effects of tuition fees on transition from high school to university in Germany. Economics of Education Review, 41, 14-23.

Caner, A., \& Okten, C. (2013). Higher education in Turkey: Subsidizing the rich or the poor? Economics of Education Review, 35, 75-92.

Cunha, J. M., \& Miller, T. (2014). Measuring value-added in higher education: Possibilities and limitations in the use of administrative data. Economics of Education Review, 42, 64-77.

Federal State Statistics Service. (2013). Statistical Yearbook of Russia. Statistics collection. Rosstat, Moscow. Retrieved from $\mathrm{http} / /$ www.gks.ru/wps/wcm/connect/rosstat_main/rosstat/ru/statistics/publications/catalog/doc_1135087342078

Filatova, L., Abankina, I., Abankina, T., \& Nikolayenko, E. (2012). Education development trends in Russia. Journal of US-China Public Administration, 9(10), 1198-1214.

Flabbi, L., Paternostro, S., \& Tiongson, E. R. (2008). Returns to education in the economic transition: A systematic assessment using comparable data. Economics of Education Review, 27(6), 724-740.

Huebner, M. (2012). Do tuition fees affect enrollment behavior? Evidence from a "natural experiment" in Germany. Economics of Education Review, 31(6), 949-960.

Impact of the Economic Crisis on European Universities. (2011). European University Association. Retrieved from $\mathrm{http} / /$ www.eua.be/Libraries/Newsletter/Economic_monitoringJanuary2011 final.sflb.ashx

Kapeliushnikov, R. I. (2012). Skolko stoit chelovecheskiy capital Rossii (How much does the Russian human capital costs)? Moscow: Publishing House of the Higher School of Economics.

Kazantsev, A. K., \& Nikitina, I. A. (2004). Natsionalnaya sistema podgotovki nauchnyh kadrov vysschey kvalifikatsii: sostoyanie i problemy razvitiya (National system of training academic staff of highest qualification: Current situation and problems of development). News of Saint Petersburg University, 8(1), 135-164.

Koritsky, A. V. (2010). Chelovecheskiy capital kak phaktor ekonomicheskogo rosta regionov Rossii (Human capital as a factor of economic growth in the regions of Russia). Novosibirsk: Siberian University of Consumer Cooperation.

O'Hear, M. F., \& MacDonald, R. B. (1995). A critical review of research in developmental education: Part I. Journal of Developmental Education, 19(2), 2-5.

Oschepkov, A. Y. (2010). Economic return on education: Interregional variation and its factors. Proceedings from the XI International Scientific Conference on Economics and Society Development. April 6-9, National Research University Higher School of Economics, Moscow.

Partanen, A. (2011). What Americans keep ignoring about Finland's school success. Retrieved from $\mathrm{http}: / / \mathrm{m}$.theatlantic.com/national/archive/2011/12/what-americans-keep-ignoring-about-finlands-school-success/250564/

Psacharopoulos, G., \& Patrinos, H. A. (2004). Returns to investment in education: A further update. Education Economics, 12(2), 111-134.

Romer, P. M. (1990). Endogenous technological change. Journal of Political Economy, 98(5), 71-102.

Rozada, M. G., \& Menendez, A. (2002). Public university in Argentina: Subsidizing the rich? Economics of Education Review, 21(4), 341-351.

Russian employee: Education, profession, qualification. (2011). Moscow: Publishing house of the Higher School of Economics. 
Sahlberg, P. (2011). Finnish Lessons: What can the world learn from educational change in Finland? New York: Teachers College Press.

Sheng-jun, Y. (2011). Educational policies and economic growth in BRICs: Comparative perspectives. Journal of US-China Public Administration, 8(2), 188-197.

Sianesi, B., \& Van Reenen, J. (2003). The returns to education: Macroeconomics. Journal of Economic Surveys, 17(2), 157-200.

Solow, R. M. (1957). Technical change and the aggregate production function. The Review of Economics and Statistics, 39(3), 312-320.

Wolff, E. N., Baumol, W. J., \& Saini, A. N. (2014). A comparative analysis of education costs and outcomes: The United States vs. other OECD countries. Economics of Education Review, 39, 1-21. 